\title{
SIMON CLASH: THE GALAXY'S GREATEST HERO
}

\author{
All in a day's work.
}

\section{BY JAMES AQUILONE}

A brzzt-brzzt-brzzt came stuttering through the air as we sped over the black sands of Desolation. Something hit the repulsor-cycle's rear fin, sending it into a vicious spin. Ja-bot was immediately thrown. I fought to regain control, and had nearly stopped the ever-widening gyre, but the cycle caught the edge of a dune and pitched me into the burning sand.

I was unhurt, beside what appeared to be a pointy shard of bone poking out just above my boot. I stood, tightened my laces, and watched as a sand skiff swooped down from the supernova-bright sky. Harvesters! The organ-jackers must have been desperate if they were operating on this miserable rock.

I gripped my sonic wand, and when the six Harvesters leaped out of their skiff, I gave it a sharp flick - which should have produced a long, pulsating laser whip. Instead, it coughed up a limp noodle of a stream that died at the Harvesters' feet. My trusty sidekick had only one responsibility before we set out to save Princess Velouria from the Dominion: to charge the damn wand!

"Ja-bot, you waste of metal!"

"My sincerest apologies, Master Clash."

Oh well, a hero of my calibre doesn't need the most powerful and versatile weapon in the Galaxy. My fists have been declared weapons of astronomical destruction in seven systems. I cracked Harvester jaws and noses with the ferocity of a three-headed Gandavian megapig, and the tiny, enshrouded creatures dropped at my feet. Except one. How the runt knocked me out with an electro-stunner, I'll never know. Ja-bot must have been blocking my view.

I awoke minutes later staring up at Desolation's triplet suns. I tried to move, but it was futile. I was pinned, naked, to a biomagnetic surgical table on the skiff's deck. Ja-bot lay beside me. The Harvesters had already disconnected his head. Unfortunately it was still operable.

"It's hopeless, Master Clash," Ja-bot said. "We're doomed!"

"A hero always finds a way, Ja-bot. That's what makes him a hero."

"Of course, Master Clash. Forgive my lack of faith."

A Harvester stood over me with a plasma scalpel. In his pipsqueak voice, he said: "Your organs should fetch a good price on the Ondorean black market. It's rare for a human to be found on Desolation."

The Harvester severed my left arm at the shoulder. Thanks to the surgical table, there was no pain, no blood.

"Sacrifice, Ja-bot. It's all part of the hero's struggle." I glared at the butcher. "Is that all you got, Harvester scum!"

It wasn't. The Harvester raised the plasma scalpel again.

The hero faces many challenges before his eventual triumph. What was one more?

The scalpel slid about three centimetres into my shoulder before bright bursts of purple erupted before my eyes.

When my vision returned, I was looking up at a masked figure who was nearly twice the size of a Harvester and wore the black and silver uniform of the Dominion. The Harvesters lay on the ground, both cut neatly in half.

"Dominion scum!" I said. "My day is finally looking up."

The figure slowly shook its head and then removed its mask.

"Princess Velouria!"

"Clash, you've seen better days."

"This? You should have seen me after I saved Princess Dreakia. You don't want to know what they cut off me then."

Suddenly the other four Harvesters appeared from below deck and rushed towards the princess.

"Free me, princess," I said, "so that I can rescue you."

But she must not have heard me in her terror and panic. Instead, she drew a sonic wand from her back pocket. With a flick of her wrist, a thick rope of pulsating purple light lashed out and sliced through three of the Harvesters. They fell to the ground in six pieces. The fourth Harvester leaped over $\rightarrow$ NATURE.COM

Follow Futures: Y @NatureFutures $f$ go.nature.com $/ \mathrm{mtoodm}$ the laser whip, somersaulted in the air, and with an electro-stunner in his hand, bore down on the princess.
With amazing luck, she slid to the side at the precise moment, snatched the Harvester's foot, slammed him to the ground, and with a shake of her wand fired a laser blast into his head.

The princess wiped a piece of the Harvester's brain matter off her cheek. "What was that about a rescue, Clash?"

I didn't dignify her with an answer. The princess was well known for her inappropriate sense of humour.

"We have an hour to get off Desolation," she said. "I've sent a self-tunnelling antimatter bomb to the centre of the planet."

"Why the hell would you do that?"

"After I rescued myself the first time, I discovered that Desolation is a living cosmic being. The Dominion plan on using it to destroy the Confederation."

"Oh, then you'll be needing a ride off this doomed body?"

"I was on my way to the space elevator, but I've probably wasted too much time here."

"Simon Clash is my name, rescuing princesses is my game. My ship is just two klicks to the south. I'll have you safely back in the Confederation's arms in no time."

"Speaking of arms. Don't forget yours."

Princess Velouria had retired to my ship's sleeping quarters by the time Desolation went critical. The poor thing must have been exhausted after her harrowing abduction. She had said she was on Desolation as a spy. I chalked that nonsense up to delirium.

"Another princess saved, another evil empire defeated," I said and flexed my left hand. Ja-bot had restored me in the medic bay. At least he was good for something.

"You truly are the Galaxy's greatest hero, Master Clash."

"No, no, Ja-bot, true heroes don't take credit for their heroic deeds. We let our actions speak for themselves." -

James Aquilone is an editor and writer. Visit his website at jamesaquilone.com. 